\title{
Vater Heinz, Wprowadzenie do lingwistyki, thumaczenie i redakcja: Jarosław Aptacy, Oficyna Wydawnicza ATUT, Wroclaw 2015, s. 360
}

Wprowadzenie do lingwistyki autorstwa Heinza Vatera, które ukazało się w przekładzie i redakcji Jarosława Aptacego, jest nie tylko pozycją podręcznikową, ale w szerokim tego słowa znaczeniu wprowadzeniem dla czytelnika zainteresowanego problematyką współczesnej lingwistyki. Podejmowane zagadnienia lingwistyczne prezentowane są co prawda na poziomie uniwersyteckiego kursu lingwistyki skierowanego do studentów kierunków filologicznych wszystkich trzech stopni edukacji uniwersyteckiej, jednak Wprowadzenie do lingwistyki może stanowić źródło wiedzy nie tylko dla studentów czy lingwistów, ale także dla badaczy reprezentujących inne gałęzie nauk humanistycznych (psychologia, socjologia, filozofia), czy nauk przyrodniczych i medycznych. Tematyka poszczególnych gałęzi lingwistyki bowiem zaprezentowana została z uwzględnieniem zasady przybliżeń. Autor, wychodząc od poziomu podstawowego, stopniowo wprowadza czytelnika w bardziej złożoną pod względem teoretyczno-metodologicznym problematykę. Precyzja i jasność wykładu idą w parze z systematyką tak pod względem treściowym, jak i formalnym. Pozwala to odbiorcy na efektywne czerpanie z potencjału i wartości poznawczych książki. Stanowi ona niewątpliwie pozycję, która pod względem teoretycznym i metodologicznym jest wymagająca wobec czytelnika, co nie zmienia faktu, że ma ona charakter propedeutyczny.

Wprowadzenie do lingwistyki obejmuje swoim zasięgiem językoznawstwo zarówno synchroniczne, jak i diachroniczne. Niewątpliwie największy nacisk kładzie się na językoznawstwo systemowe - to rozdziały poświęcone fonologii, morfologii, składni i semantyce (s. 68-179). Językoznawstwo historyczno-porównawcze zajmuje jeden rozdział (s. 294-312), przy czym zamieszczono tu podrozdziały poświęcone typologii języków i lingwistyce kontrastywnej. 
Do lingwistyki w sensie szerszym Autor zalicza - co nie jest dla niego samego bezdyskusyjne - pragmatykę (por. diagram na s. 25). Jako dziedziny o charakterze interdyscyplinarnym traktuje natomiast psycholingwistykę, neurolingwistykę, socjolingwistykę, lingwistykę tekstu oraz filozofię języka - wszystkie w niemieckim obszarze językowym określane jako tzw. „lingwistyki z myślnikiem" (niem. Bindestrich-linguistiken).

Rozdział wstępny o charakterze metodologiczno-wprowadzającym rozpatruje kwestie związane z rozumieniem znaczenia słowa język oraz precyzuje przedmiot badań językoznawczych. Autor wychodzi od założeń ogólnometodologicznych - opiera się na pojęciu nauki Karla Poppera, przytaczając jego zwięzłą definicję nauki. Pozwala to czytelnikowi odnieść się do głębszych podstaw ontologicznych i teoriopoznawczych różnych metodologii lingwistycznych, które Heinz Vater w książce później zaprezentuje. Wśród nich popularny współcześnie paradygmat kognitywistyczny, który - jak podaje H. Vater (za Moniką Schwarz 1996), sprawił, że współczesna lingwistyka stała się nie tylko nauką opisową, ale i wyjaśniającą. Język naturalny traktowany jest w niej jako zjawisko psychiczne. Autor wskazuje, że ten kierunek badań można traktować albo jako element językoznawstwa albo „identyfikować go z całą lingwistyką ukierunkowaną mentalnie" (s. 24).

W części poświęconej systemowemu podejściu do języka znajdujemy omówienie wszystkich najważniejszych działów lingwistyki odnoszących się do jądra systemu językowego: fonologii, morfologii, składni i semantyki.

Rozdział traktujący o zagadnieniach fonetyki i fonologii prezentuje obok tradycyjnego także strukturalistyczne podejścia do dźwiękowej strony języka. Autor przedstawia - w oparciu o funkcjonalną i fizykalistyczą definicję fonemu (Nikołaj Sergiejewicz Trubiecki, Roman Jakobson, Daniel Jones), które przyjęte są dziś jako optymalne w stosunku do innych (Jan Niecisław Baudouin de Courtenay, Edward Sapir, Louis Trolle Hjelmslev) - cechy fonologiczne dla języka niemieckiego. Opis ten zostaje przez thumacza i redaktora uzupełniony o zestawienie tych cech dla języka polskiego - egzemplarycznie dla polskich spółgłosek (s. 47). W tym kontekście redaktor zamieszcza także uwagi dotyczące problematycznego podejścia do polskich afrykat. Wyjaśnienie tego zjawiska możliwe staje się dopiero na płaszczyźnie fonologii nielinearnej, której zarysy przedstawione zostają w rozdziale 2.6. Wiele zjawisk fonetycznych znajduje wyjaśnienie w ramach gramatyki generatywnej, mającej swój wkład w rozwój zarówno fonologii diachronicznej, jak i synchronicznej. Interesującym jest uwzględnienie w pracy wielu zjawisk wykraczających poza pojedyncze segmenty dźwiękowe - przedstawienie struktur i procesów prozodycznych (struktury sylaby, struktur akcentowych wyrazów i zdań, ilo- 
czasu poszczególnych segmentów, intonacji i tonu, wreszcie także harmonii wokalicznej). Omówiona zostaje także fonologia autosegmentalna pomocna w analizie tonów i struktur sylab. Wszystkie te fenomeny dźwiękowe pozwala poznać i głębiej wyjaśnić właśnie fonologia zakładająca istnienie struktur hierarchicznych, której zarysy zostały przedstawione przez H. Vatera. Ilustrujące te zjawiska przykłady z języka polskiego są autorstwa thumacza i redaktora książki, J. Aptacego.

W rozważaniach poświęconych morfologii uwzględnione zostały najnowsze osiągnięcia z zakresu badań nad strukturą wyrazów w aspekcie słowotwórczym i fleksyjnym. Analiza struktury wyrazu odwołuje się zarówno do koncepcji deklaratywnej, jak i derywacyjnej. W przypadku analizy deklaratywnej formy morfologiczne thumaczone są za pomocą zasad i regut (Wolfgang Ulrich Wurzel, Martin Neef). Teoria dizajnu wyrazu Martina Neefa (niem. Wortdesign) próbuje obejść się bez pojęcia morfemu, tłumacząc regularności morfologiczne w kategoriach tzw. warunków dizajnu. Obok zagadnień fleksyjnych dużo miejsca poświęconych zostaje słowotwórstwu. Przy czym Autor zwraca uwagę na nachodzenie się fleksji i słowotwórstwa w wielu obszarach analizy struktur wyrazowych. Omawia podstawowe procesy słowotwórcze: złożenia, derywacje, konwersje, kontaminacje, zapożyczenia i skrótowce. Wyróżnia specyficzny typ złożeń, jakimi są derywaty desyntagmatyczne (niem. Zusammenbildungen). Ten wyodrębniany typ złożeń opiera się na odmiennej interpretacji powstawania nowych struktur wyrazowych od istniejącej w obrębie tradycji opisu słowotwórczego w języku polskim.

Rozdział dotyczący składni prezentuje podstawowe zagadnienia związane z kategorią struktur frazowych i zdania. Autor nie tylko wyjaśnia co jest przedmiotem składni, ale daje również przegląd podstawowych kierunków jej rozwoju, poczynając od analizy zdania metodą składników bezpośrednich oraz gramatyki frazowej aż do generatywizmu Noama Chomsky'ego zarówno w wersji tzw. teorii standardowej, jak i rozszerzonej - teoria GB (teoria rządu i wiązania) i Minimalist Program MP (program minimalistyczny). Szkicuje architekturę gramatyki, opierając się na ujęciach stricte strukturalistycznych, także generatywistycznych, wskazuje jednak również na inne doniosłe współczesne teorie gramatyczne jak: gramatykę dependencyjną, funkcjonalną, leksykalistyczno-funkcjonalną czy wreszcie uogólnioną gramatykę struktur frazowych, odsyłając jednocześnie czytelnika do odnośnej literatury przedmiotu.

W części poświęconej semantyce omówiono podstawowe zagadnienia z zakresu semantyki logicznej (relacje logiczne) oraz semantyki językoznawczej. W ramach tej ostatniej wyjaśnione zostają podstawowe relacje semantyczne: synonimii, hiponimii, podobieństwa, niezgodności i komplementar- 
ności. Przedstawione zostają także rodzaje analizy znaczenia: za pomocą postulatów semantycznych oraz cech semantycznych.

W rozdziale dotyczącym pragmatyki Autor najpierw dokonuje jasnego odróżnienia pragmatyki od semantyki, po czym omawia szczegółowo teorię aktów mowy, przeprowadzając dyskusję z podanymi przez Johna Rogersa Searla warunkami fortunności aktów mowy. Kolejnym zagadnieniem, które porusza, to problematyka implikatur w kontekście maksym konwersacyjnych Herberta Paula Grice'a. Również ten rozdział - co zasługuje na uwagę - obok tych poruszających zagadnienia lingwistyki systemowej zamykają ćwiczenia, co często trudno można odnaleźć w opracowaniach propedeutycznych o podobnym charakterze.

Nawiązując do teoretycznych założeń i sformułowanej przez Noama Chomsky’ego koncepcji języka jako organu umysłu ludzkiego - co wiąże się z wiedzą na temat struktur poznawczych człowieka - Autor skłania się ku badaniu przez językoznawcę tego, co Noam Chomsky nazywa human mind. Wydaje się, że w związku z tym na odrębne potraktowanie zasługuje psycholingwistyka, której w książce poświęcono sporo uwagi - rozdział dotyczący psycholingwistyki jest objętościowo najobszerniejszy - obejmuje 41 stron. Po nim następuje rozdział poświęcony neurolingwistyce, której zagadnienia korespondują z problematyką badawczą nauk przyrodniczych, a zwłaszcza medycyny.

Autor odwołuje się do paradygmatu metodologicznego współczesnego językoznawstwa kognitywnego, co uwydatnia się już w rozdziale dotyczącym przedmiotu językoznawstwa (por. s. 23-24). Ślady odwołań do kognitywnych podstaw zjawisk językowych widoczne są również w rozdziale dotyczącym semantyki. Niewątpliwie niektóre zjawiska składniowe są także interpretowane na gruncie kognitywnym, jeśli - jak zaznacza sam Autor - za Manfredem Bierwischem generatywistyczne teorie opisu składniowego uznać za pośrednio powiązanie z programem kognitywnym, uznając jednocześnie jego wpływ na rozwój gramatyki generatywnej.

Psycholingwistyce poświęcony jest odrębny rozdział. Omówione zostały tu zagadnienia związane z systemami i procesami kognitywnymi, reprezentacją języka w umyśle ludzkim oraz percepcją i przetwarzaniem mowy, a także przejęzyczeniami, które były przedmiotem szczególnego zainteresowania naukowego H. Vatera. Autor przedstawia za Ulrichem Schade (1992) klasyfikację przejęzyczeń. Wyróżnione i omówione zostają: przejęzyczenia polegające na zamianie, antycypacji, perseweracji i kontaminacji. Problematyka percepcji mowy omówiona zostaje z perspektywy modeli autonomicznych $\mathrm{i}$ interaktywnych. Powiązane $\mathrm{z}$ tym zagadnieniem są zaprezentowane w pracy 
modele rozpoznawania słów: logogenowy Johna Mortona i kohorty Williama Marslena-Wilsona/Lorraine K. Tyler lub Williama Marslena-Wilsona/Alana Welsha, a także model treningowo-aktywujący Jamesa McClellanda/Davida Rumelharta. W dalszej części omawiana jest problematyka akwizycji języka wraz z przedstawieniem procesów zachodzących przy przyswajaniu głosek, składni i semantyki. Rozdział dotyczący psycholingwistyki zamyka krótkie omówienie zagadnienia relacji pomiędzy mową a myśleniem.

Problematyka interdyscyplinarnego podejścia do lingwistyki otwiera rozdział poświęcony socjolingwistyce. Omawia on kwestie przedmiotu tej dziedziny wiedzy językoznawczej, problematykę konwersacji oraz analizy konwersacyjnej. Kolejnym rozdziałem poświęconym interdyscyplinarnemu charakterowi badań językoznawczych jest - jakże dziś chętnie uprawiana z różnych pozycji metodologicznych - dziedzina lingwistyki tekstu. H. Vater pokazuje to metodologiczne zróżnicowanie, dyskutując jednocześnie niektóre ujęcia kategorii tekstu oraz tekstualności. Szczególnie te, które na stałe zagościły już w lingwistyce tekstu, jak na przykład definicję tekstu Roberta-Alaina de Beaugrande'a/Wolfganga Ulricha Dresslera (1981) z podanymi przez nich kryteriami tekstualności. W dalszej części Autor omawia jeszcze koncepcję makro- i mikrostruktury Teuna van Dijka, jak i wprowadzone do badań struktury tekstu pojęcie „questio” Wolfganga Kleina/Christiane von Stutterheim (1987). Omawiane kwestie wytwarzania tekstu Autor uzupełnia o komponent jego rozumienia. Tu odwołuje się do kategorii horyzontu zaproponowanej przez Maximiliana Schernera (1984) oraz - także autorstwa Maximiliana Schernera - metafory śladu, która pozwala na przedstawienie kategorii tekstu jako językowego zdarzenia komunikacyjnego, danego materialnie w formie dostrzegalnego znaku. Rozdział podejmujący problematykę filozofii języka dyskutuje kwestie różnicy metodologicznej pomiędzy filozoficznym podejściem do języka naturalnego a językoznawczym podejściem empirycznym.

Poświęcony językoznawstwu porównawczemu dział obejmuje swoim zakresem podstawowe zagadnienia zarówno w perspektywie diachronicznej (genetycznej), jak i synchronicznej (typologicznej). Część historyczna traktuje o rodzinach językowych oraz o podstawowych procesach językowych w przebiegu jego rozwoju. Tu też znalazł się podrozdział autorstwa tłumacza i redaktora tekstu, Jarosława Aptacego, dotyczący historii języka polskiego. Jeśli chodzi o typologię językową, to przedstawiono jej tradycyjną wersję, polegającą na uwypuklaniu różnic, wskazano jednak również nowsze tendencje badań w tej dziedzinie podejmujące tę problematykę z perspektywy uniwersaliów językowych, zarówno w jej wariancie bardziej abstrakcyjnym (badanie mniejszej liczby języków), jak i konkretniejszym (odnoszącym się do większej 
liczby języków). Część porównawcza zakończona jest rozdziałem dotyczącym bujnie rozwijających się badań kontrastywnych, gdzie na przykładzie różnic fonologicznych pomiędzy językiem niemieckim a angielskim zilustrowano charakter analiz kontrastywnych.

Podręcznikowy charakter pozycji podkreślają ćwiczenia zamieszczone w rozdziałach od 2 do 5, poświęcone lingwistyce systemowej i pragmatyce. Są one nieocenioną pomocą $\mathrm{w}$ dydaktyce nauczania tego przedmiotu, tym bardziej, że podzielone są na część opatrzoną kluczem i część bez klucza. Niektóre z nich mają charakter otwarty, dopuszczając w odpowiedzi więcej interpretacji.

Omawiana pozycja prezentuje holistyczne podejście do zagadnień językowych. Rzeczywistość języka stanowi spójną całość i może zostać poddana oglądowi z różnych perspektyw. Zarazem poszczególne działy nauki o języku zazębiają się ze sobą, a Autor pokazuje powiązania pomiędzy nimi. Te różne perspektywy to także różne metodologie, aplikowane adekwatnie do badanego obiektu lingwistycznego. H. Vaterowi w ich prezentacji udaje się osiągnąć efekt spójnego pluralizmu.

Na osobną i wyjątkową uwagę zasługuje przekład i redakcja, autorstwa Jarosława Aptacego, któremu udało się dostosować dzieło H. Vatera do polskiego odbiorcy jako rodzimego użytkownika języka. W rezultacie do rąk polskiego czytelnika trafia przekład pragmatyczny w szerokim tego słowa znaczeniu. Obejmuje on bowiem także rozdziały, które napisane zostały przez thumacza całkowicie na nowo (por. rozdział Historia języka polskiego w skrócie oraz fragment poświęcony historii ortografii polskiej). J. Aptacy bardzo precyzyjnie dobrał polską terminologię językoznawczą. Na podkreślenie zasługuje staranność w przywoływaniu i interpretacji polskich przykładów ilustrujących poszczególne zjawiska językowe. Zwraca również uwagę adekwatność doboru tłumaczeń z literatury pięknej na język polski. Niektóre z przykładów w języku oryginalnym pochodzą z niemieckich poetyckich tekstów literackich. Niekiedy ze względów pragmatycznych J. Aptacy teksty te zastąpił adekwatnymi polskimi tekstami literackimi. Całość tłumaczenia podręcznika Heinza Vatera przyjmuje perspektywę odbiorcy, którego rodzimym językiem jest język polski. Można śmiało powiedzieć, że dzięki Jarosławowi Aptacemu udało się przenieść dorobek językoznawstwa germanistycznego (również anglojęzycznego) na grunt polski. Heinz Vater, którego za życia łączyły silne więzy z Polską, z polskimi germanistami i językoznawcami, pozostawił po sobie pozycję, która tę specyficznie polsko-niemiecką kontrastywną perspektywę językoznawczą upowszechnia i pogłębia. W efekcie czego możemy dostrzec różnice nie tylko 
w ujmowaniu fenomenu języka, ale również w tradycji opisu gramatycznego i szerzej językoznawczego obu języków. Jeśli za Maximilianem Schernerem teksty są śladem językowego zdarzenia komunikacyjnego, to ten tekst pozostawia po sobie w odniesieniu do czytelnika polskiego ślad pod wieloma względami wyjątkowy i specyficzny.

Andrzej Marniok 